\title{
Erratum to: Enhancing the Role and Effectiveness of Corporate Social Responsibility (CSR) Reports: The Missing Element of Content Verification and Integrity Assurance
}

\author{
S. Prakash Sethi ${ }^{1} \cdot$ Terrence F. Martell $^{1} \cdot$ Mert Demir $^{1}$
}

Published online: 21 October 2016

(C) Springer Science+Business Media Dordrecht 2016

Erratum to: J Bus Ethics

DOI 10.1007/s10551-015-2862-3

The footnote for Table 5 should read:

$* p<0.10, * * p<0.05, * * * p<0.01$

Additionally, an error occurred as a consequence of transferring data from one computer program to another, which resulted in the changing of the direction of some $t$ statistics. This had no impact on the conclusions.

The correct version of Table 12, with the corrections in bold, can be found below:

The online version of the original article can be found under doi:10.1007/s10551-015-2862-3.

\section{S. Prakash Sethi}

prakash.sethi@baruch.cuny.edu

1 Weissman Center for International Business, Baruch College, The City University of New York, Box J-1034, One Bernard Baruch Way, New York, NY 10010, USA 
Table 12 Determinants of CSR assurance decision and quality
Dependent variable

(Logit)

Assurance dummy

$0.157 * * *$

(9.22)

$13.14 * * *$

(5.01)

FINANCE

PRODUCTION

OIL AND GAS

UTILITIES

FIRM SIZE

$R O A$

LAW

NATIONALCSR

ADRI

\begin{tabular}{l} 
Dependent variable \\
\hline Selection regression \\
PERCASSURED
\end{tabular}

$-0.585$

$(-1.34)$

0.0465

(0.15)

$-0.458$

$(-0.96)$

0.629

(1.43)

0.0614

(0.93)

$-2.977 * * *$

$(-3.05)$

0.332

(1.23)

$-0.122 * * *$

(-5.14)

$-0.112$

$(-0.74)$

$.164 * * *$

(5.6)

$0.129 * * *$

(3.61)

$2.230 * *$

$2.344 * *$

(2.19)

(2.33)

$-0.336$

$-0.343$

$(-0.92)$

$(-0.95)$

$2.601 * * *$

$2.578 * * *$

(2.9)

0.396

0.191

(0.47)

$-0.360 * *$

$(-2.47)$

2.333

(1.44)

$-2.213 * * *$

$(-3.51)$

0.0065

(0.1)

$0.889 * * *$

(0.2)

$-0.341^{* *}$

$(-2.46)$

$2.702 *$

(1.84)

$-2.099 * * *$

$(-3.57)$

0.0246

(0.38)

$0.803 * * *$

(3.56)

(3.72)
(Logit)

Assurance dummy

(OLS)

Assurance dummy Assurance score $6.165 * * *$ (3.98)

Likelihood ratio $X^{2}$ N 460 403

$t$-statistics in parentheses

$* p<0.10, * * p<0.05, * * * p<0.01$ 